\title{
GMR
}

\section{Genetic diversity among Hymenaea courbaril L. genotypes naturally occurring in the north of Mato Grosso State, Brazil}

\author{
V.D. Rocha ${ }^{1}$, P.V. Tiago ${ }^{2}$, A.V. Tiago ${ }^{3}$, E.C.M. Pedri ${ }^{2}$, E.S. Cardoso ${ }^{2}$ and \\ A.A.B. Rossi ${ }^{4}$ \\ ${ }^{1}$ Laboratório de Genética Vegetal e Biologia Molecular, \\ Curso de Ciências Biológicas, Faculdade de Ciências Biológicas e Agrárias, \\ Universidade do Estado de Mato Grosso, Campus de Alta Floresta, \\ Alta Floresta, MT, Brasil \\ ${ }^{2}$ Programa de Pós-Graduação em Biodiversidade e Agroecossistemas Amazônicos, \\ Laboratório de Genética Vegetal e Biologia Molecular, \\ Universidade do Estado de Mato Grosso, Campus de Alta Floresta, \\ Alta Floresta, MT, Brasil \\ ${ }^{3}$ Programa de Pós-Graduação em Biodiversidade e Biotecnologia Rede BIONORTE, \\ Laboratório de Genética Vegetal e Biologia Molecular, \\ Universidade do Estado de Mato Grosso, Campus de Alta Floresta, \\ Alta Floresta, MT, Brasil \\ ${ }^{4}$ Laboratório de Genética Vegetal e Biologia Molecular, \\ Faculdade de Ciências Biológicas e Agrárias, \\ Universidade do Estado de Mato Grosso, Campus de Alta Floresta, \\ Alta Floresta, MT, Brasil \\ Corresponding author: A.A.B. Rossi \\ E-mail anabanrossi@unemat.br \\ Genet. Mol. Res. 16 (3): gmr16039706 \\ Received April 20, 2017 \\ Accepted July 20, 2017 \\ Published July 28, 2017 \\ DOI http://dx.doi.org/10.4238/gmr16039706
}

Copyright (C) 2017 The Authors. This is an open-access article distributed under the terms of the Creative Commons Attribution ShareAlike (CC BY-SA) 4.0 License.

ABSTRACT. Hymenaea courbaril L. is a tropical tree species with economic and medicinal potential largely used in programs for the recovery of degraded areas. The use of molecular markers in genetic studies can

Genetics and Molecular Research 16 (3): gmr16039706 
help in the definition of forest restoration strategies. This study was conducted to analyze the genetic diversity among $H$. courbaril ('jatobá') genotypes naturally occurring in the north of Mato Grosso State, Brazil, using ISSR markers, aiming to contribute to the development of seed collection and seedling production strategies. Twenty-four $H$. courbaril individuals were sampled by collecting leaves for DNA extraction by the CTAB method. The individuals were genotyped using 14 ISSR primers, resulting in the amplification of 87 bands in total, 65 of which were polymorphic. The ISSR markers presented average polymorphism information content of 0.44. Dissimilarity values based on the Jaccard coefficient ranged from 0.12 to 0.52 . The most divergent individuals were 3 and 22, whereas 14 and 19 were the most genetically similar. The UPGMA and Tocher clustering methods indicated the formation of four distinct groups, revealing genetic variability among the $24 \mathrm{H}$. courbaril genotypes. Therefore, all the evaluated genotypes can be used for seed collection and seedling production, but the most divergent individuals should be prioritized.

Key words: Jatobá; ISSR; Seed collection; Reforestation

\section{INTRODUCTION}

Hymenaea courbaril L. (Leguminosae) is a tropical tree species popularly known as 'jatobá' that occurs naturally from the south of Mexico to South America, including Brazil, the French Guiana, Suriname, Guiana, Venezuela, Colombia, Peru, and Bolivia. In Brazil, it is present from the north to the southeast regions (Melo and Mendes, 2005). The wide geographic distribution of this species indicates tolerance and adaptation to different environments; for this reason, it is recommended for programs of recovery of degraded forest areas (Oliveira et al., 2011).

Timber is the most commercialized product from jatobá, used in the manufacture of furniture and construction. The bark of its trunk and its fruit are used in the combat against the flu, bronchitis, anemia, and prostate diseases (Marinho et al., 2011). Rural populations in regions where this plant occurs consume the farinaceous pulp that coats its seeds, which is a highly nutritious edible product (Lorenzi and Matos, 2002).

With the advance of agricultural frontiers, logging, construction of hydroelectric plants, and real estate speculation, Brazilian forest formations have undergone considerable levels of disturbance, which may lead to loss and genetic erosion of forest species like jatobá. As a result, initiatives for the execution of preservation projects and sustainable use and recovery of degraded pastures are growing, especially those involving the use of native species (Pacheco et al., 2013).

Knowledge of genetics and ecology in natural populations of tropical tree species are essential for the development of activities defining the size of reserves, adequate management of species, recovery of degraded areas, and collection of seeds for the planting of native species (Kageyama et al., 2003).

For the restoration of forests, it is important to maintain the genetic diversity found in natural populations to ensure the conservation of new populations inserted in the reforested area (Gois et al., 2014). The success of programs for the recovery of areas depends on the

Genetics and Molecular Research 16 (3): gmr16039706 
genetic potential of the material used in reforestation (Sebbenn, 2002). Therefore, genetic studies should be carried out with native plants employed in reforestation, since they help to identify mother trees with the greater genetic variability that can supply seeds for seedling production programs.

Various molecular techniques are available for the analysis and detection of genetic variability at DNA level. Among them are the ISSR (inter-simple sequence repeats) molecular markers, which can be used in the discrimination and molecular characterization of individuals. These markers are genomic regions of 100 to $3000 \mathrm{bp}$ amplified via polymerase chain reaction using a single primer pair (16-20 bp); they are developed from microsatellite sequences (Faleiro, 2007). Some outstanding advantages of the ISSR technique are its low cost, high polymorphism, and the fact that it does not require previous information on the DNA sequence of the organism under study (Santana et al., 2011).

Given the potential use of jatobá for the recovery of degraded pasture, we developed this study to analyze the genetic diversity among $H$. courbaril (jatobá) genotypes occurring naturally in the north of Mato Grosso State, Brazil, using ISSR markers, aiming to provide information for the development of seed collection and seedling production strategies.

\section{MATERIAL AND METHODS}

\section{Collection of plant material}

Young leaves were collected from $24 \mathrm{H}$. courbaril individuals naturally occurring in the north region of Mato Grosso State (Brazil), in the municipalities of Sinop, Itaúba, Colíder, and Nova Canãa do Norte (Figure 1). The collected material was identified and packed with silica gel, and later transported to the Laboratory of Plant Genetics and Molecular Biology at the Universidade do Estado do Mato Grosso, where it was stored in a freezer at $-20^{\circ} \mathrm{C}$ until DNA extraction.

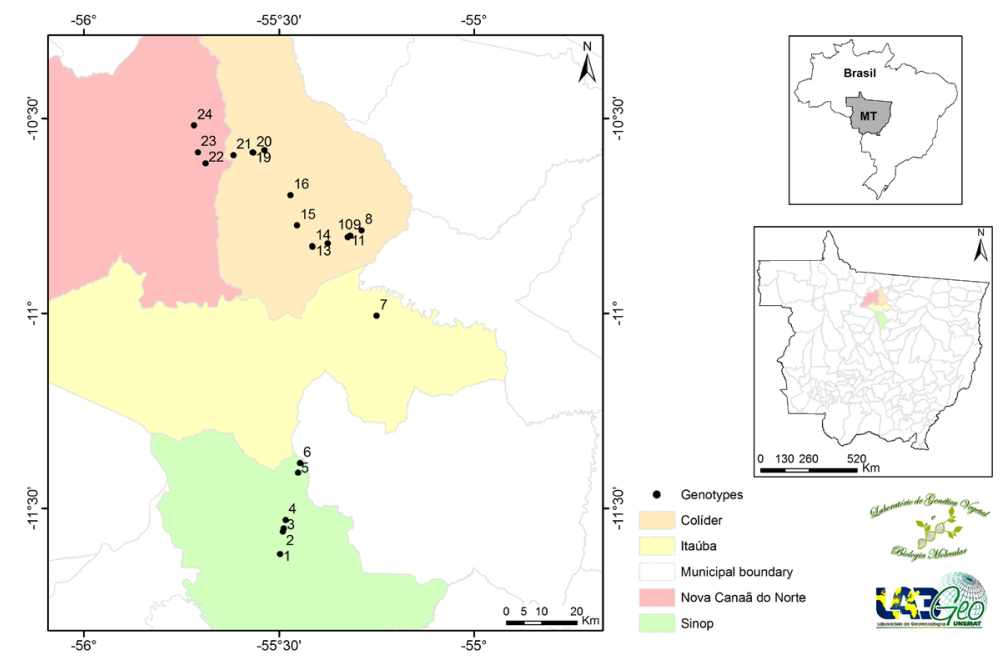

Figure 1. Geographical location of the 24 Hymenaea courbaril genotypes naturally occurring in the north of the Mato Grosso State, municipalities of Sinop, Itaúba, Colíder, and Nova Canãa do Norte.

Genetics and Molecular Research 16 (3): gmr16039706 


\section{Genomic DNA extraction}

The DNA was extracted by the CTAB (cetyltrimethylammonium bromide) method described by Doyle and Doyle (1987), with modifications: the polyvinylpyrrolidone concentration was increased from 1 to $2 \%$; CTAB from 2 to $5 \%$; and $\beta$-mercaptoethanol from 0.2 to $2 \%$, in addition to reducing the incubation time in water bath at $65^{\circ} \mathrm{C}$ from 60 to $30 \mathrm{~min}$. The quality of the extracted DNA was evaluated on $1 \%$ agarose gel stained with ethidium bromide. For the quantification, the DNA samples were compared with standard DNA (lambda phage).

\section{Selection of ISSR primers and amplification reactions}

We tested 30 ISSR primers obtained from the University of British Columbia for DNA amplification. Of these, we selected 14 primers that produced a larger number of clear bands and reproducible polymorphism. Each amplification reaction contained a final volume of 15 $\mu \mathrm{L}$, consisting of $1 \mu \mathrm{L}$ DNA ( $20 \mathrm{ng} / \mu \mathrm{L}$ ), $2 \mu \mathrm{L} 5 \mathrm{X}$ buffer (GoTaq colorless), $2 \mu \mathrm{L} \mathrm{MgCl}_{2}$ (25 $\mathrm{mM}), 2 \mu \mathrm{L}$ primer $(0.2 \mu \mathrm{M}), 4 \mu \mathrm{L}$ dNTPs $(1 \mathrm{mM}$ of each dNTP), $0.5 \mu \mathrm{L}$ BSA, $0.15 \mu \mathrm{L}$ Taq DNA polymerase, and $3.4 \mu \mathrm{L}$ autoclaved distilled water.

Reactions were conducted in a thermal cycler (MJ 96) under the following amplification conditions: one initial denaturation cycle at $94^{\circ} \mathrm{C}$ for $4 \mathrm{~min}$, followed by 35 cycles at $94^{\circ} \mathrm{C}$ for $1 \mathrm{~min}, 50-59^{\circ} \mathrm{C}$ (temperature of the primer used) for $1 \mathrm{~min}, 72^{\circ} \mathrm{C}$ for $3 \mathrm{~min}$, and one final extension at $72^{\circ} \mathrm{C}$ for $7 \mathrm{~min}$.

The amplification products were separated by electrophoresis in a horizontal unit using $1.5 \%$ agarose gel in $1 \mathrm{X}$ TBE buffer at a constant voltage of $90 \mathrm{~V}$. After electrophoresis the gels were stained with ethidium bromide $(0.6 \mathrm{ng} / \mu \mathrm{L})$ for $20 \mathrm{~min}$; next, they were visualized under UV transillumination and photo-documented. The sizes of the amplified fragments were estimated by comparison with the 100-bp DNA Ladder molecular marker (Kapa).

\section{Statistical analyses}

The ISSR fragments were coded to build a matrix as binary characters to the presence (1) or absence (0) of bands. The bands that showed weak color and low definition were not evaluated. With the binary matrix, we calculated the percentage of polymorphisms obtained per primer and the genetic diversity of the locus or PIC (polymorphism information content), which is an estimate used for the evaluation of the discriminatory power of a locus. To calculate the PIC of each primer, we used the equation proposed by Rezende et al. (2009). The genetic dissimilarity estimate between each pair of individuals was calculated by the Jaccard coefficient, using the arithmetic complement. A cluster analysis of the genotypes was performed by the UPGMA (unweighted pair-group method arithmetic mean), Ward, and nearest neighbor hierarchical methods. To select the hierarchical method with greatest clustering consistency, we calculated the cophenetic correlation coefficient (CCC) between the genetic similarity matrix and the matrix of cophenetic coefficients. A cluster analysis of the genotypes by Tocher's optimization approach was also performed, using the distance matrix generated by the arithmetic coefficient of the Jaccard index. Analyses were run in the GENES software (Cruz, 2006).

\section{RESULTS AND DISCUSSION}

Eighty-seven (87) fragments were generated with the use of the 14 ISSR primers,

Genetics and Molecular Research 16 (3): gmr16039706 
65 of which were polymorphic (74.71\%). The number of amplified bands ranged from two $\left[\mathrm{Di}(\mathrm{GA})_{8} 3^{\prime} \mathrm{YC}\right]$ to eleven $\left[\mathrm{Di}(\mathrm{AG})_{8} 3^{\prime} \mathrm{C}\right]$, with an average of 6.21 per primer (Table 1). These results are similar to those found in other tropical tree species. Silva et al. (2017) found 64 polymorphic bands, with an average of 6.97 bands per primer, using 14 ISSR markers in a study of genetic diversity in Spondias mombin L. Rivas et al. (2013) characterized the genetic diversity of Theobroma subincanum Mart. populations using 13 ISSR primers and obtained $67.20 \%$ polymorphism at the species level, with an average of 4.69 bands per primer.

Table 1. Inter-simple sequence repeat primers used and respective sequences, annealing temperature (AT), total number of amplified bands (TNB), number of polymorphic bands (NPB), polymorphism percentage (\%P), and polymorphism information content (PIC) for 24 Hymenaea courbaril genotypes with natural occurrence in the north of the Mato Grosso State.

\begin{tabular}{l|l|c|c|c|c|c}
\hline Primer & Sequence (5'-3') & AT & TNB & NPB & $\%$ P & PIC \\
\hline Di(AG)83'C & AGAGAGAGAGAGAGAGC & 50 & 11 & 10 & 90.90 & 0.56 \\
\hline Di(CA)8'G & CACACACACACACACAG & 51 & 4 & 4 & 100.00 & 0.52 \\
\hline Tri(ATG)6 & ATGATGATGATGATGATG & 50 & 6 & 2 & 33.00 & 0.18 \\
\hline Di(AG)83'G & AGAGAGAGAGAGAGAGG & 50 & 7 & 5 & 71.43 & 0.44 \\
\hline Di(CA)83'A & CACACACACACACACAA & 50 & 5 & 5 & 100.00 & 0.74 \\
\hline Di(AC)83'T & ACACACACACACACACT & 51.4 & 7 & 6 & 85.71 & 0.83 \\
\hline Di(AC)83'C & ACACACACACACACACC & 50 & 4 & 3 & 75.00 & 0.36 \\
\hline Di(GA)83'YC & GAGAGAGAGAGAGAGAYC & 50 & 2 & 1 & 50.00 & 0.22 \\
\hline Di(AC) $83^{\prime} Y G$ & ACACACACACACACACYG & 52 & 5 & 5 & 100.00 & 0.58 \\
\hline Di(AC)7'DBD & DBDACACACACACACAC & 50 & 10 & 8 & 80.00 & 0.51 \\
\hline Di(CA)85'CY & CYCACACACACACACACA & 58.8 & 9 & 5 & 55.56 & 0.23 \\
\hline Tri(ACA)53'RC & ACAACAACAACAACARC & 50 & 6 & 6 & 100.00 & 0.70 \\
\hline Di(GA)85'CY & CYGAGAGAGAGAGAGAGA & 50 & 6 & 2 & 33.00 & 0.03 \\
\hline Di(CA)75'BDB & BDBCACACACACACACA & 50 & 5 & 3 & 60.00 & 0.28 \\
\hline Average & & & 6.21 & 4.64 & 73.95 & 0.44 \\
\hline Total & & & 87 & 65 & & \\
\hline
\end{tabular}

$\mathrm{Y}=\mathrm{C}$ or $\mathrm{T} ; \mathrm{B}=\mathrm{C}, \mathrm{G}$ or $\mathrm{T} ; \mathrm{R}=\mathrm{A}$ or $\mathrm{G} ; \mathrm{D}=\mathrm{A}, \mathrm{G}$ or $\mathrm{T}$.

Among the ISSR markers used, those that generated the largest part of the polymorphism contained CA, AC, and AG repetitions. Reddy et al. (2002) stated that primers with repetitions (AG), (GA), (CT), (TC), (AC), and (CA) present more polymorphism than those with other repeated di-, tri-, or tetranucleotides; this explains the results found here.

The PIC ranged from 0.03 to 0.83 , and the primers $\mathrm{Di}(\mathrm{AC})_{8} 3^{\prime} \mathrm{T}$, $\mathrm{Di}(\mathrm{CA})_{8} 3^{\prime} \mathrm{A}$, and Tri (ACA) ${ }_{5} 3$ 'RC presented the highest values: $0.83,0.74$, and 0.70 , respectively (Table 1 ). According to Botstein et al. (1980), markers with PIC values higher than 0.5 are considered very informative; those with values between 0.25 and 0.5 are considered moderately informative, and markers with PIC values lower than 0.25 are little informative. In the present study, the average PIC was 0.44 , and so we can consider that the ISSR primers were moderately informative to reveal polymorphism in the jatobá individuals; this confirms that the markers utilized were efficient to estimate genetic diversity in $H$. courbaril since ISSR classified as moderately informative have been successfully used in other species, e.g., Ficus bonijesulapensis R.M. Castro (Duarte et al., 2015), Hancornia speciosa Gomes (Costa et al. 2015), Mimosa caesalpiniaefolia Benth. (Araújo et al., 2016), and Theobroma grandiflorum (Willd. ex Spreng.) K. Schum (Silva et al., 2016).

The genetic dissimilarity values ranged from 0.12 to 0.52 (Table 2 ). The genotypes that showed the lowest dissimilarity were 14 and 19, whereas the most divergent were 3 and 22 . Rodrigues et al. (2016) evaluated the genetic variability of Byrsonima crassifolia (L.) H.B.K. from the germplasm database of Embrapa Amazônia Oriental and identified dissimilarity

Genetics and Molecular Research 16 (3): gmr16039706 
values between 0.10 and 0.59 . Lorenzoni et al. (2014) studied the genetic diversity among Rollinia тисова [Jacq.] Baill. genotypes with ISSR markers and found dissimilarity values ranging from 0.09 to 0.51 , indicating high genetic variability among the accessions. We can thus infer that the dissimilarity results found in this study demonstrate the existence of a considerable genetic diversity among the $H$. courbaril genotypes.

Table 2. Jaccard's genetic dissimilarity matrix among the 24 Hymenaea courbaril genotypes with natural occurrence in the north of the Mato Grosso State, analyzed by ISSR markers.

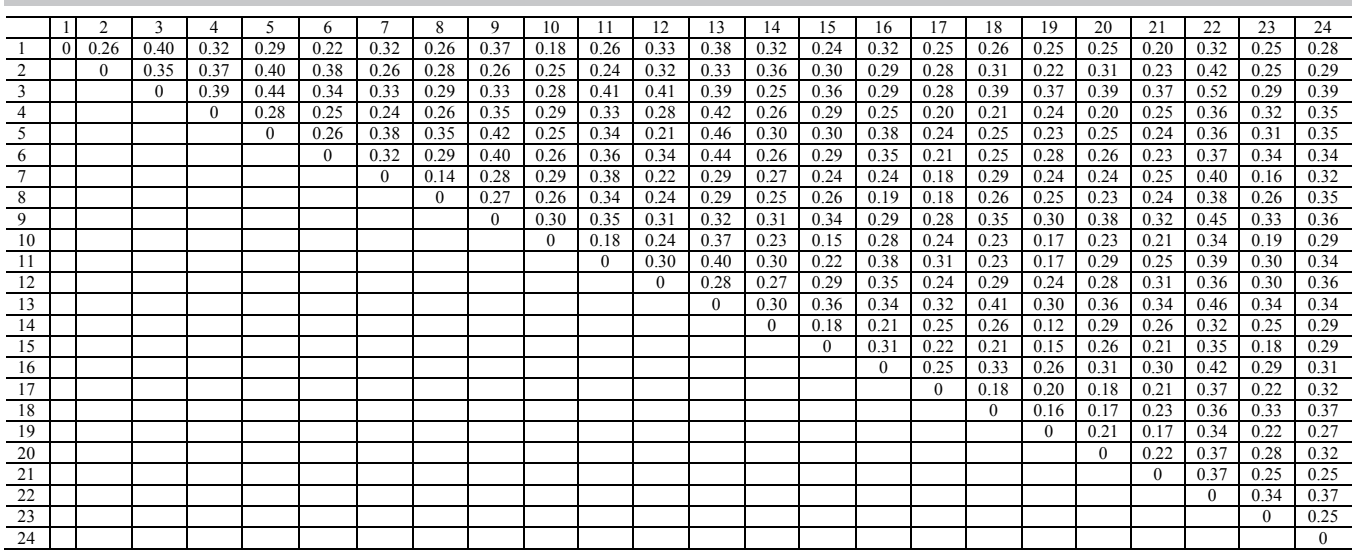

Among the hierarchical clustering methods (UPGMA, WARD, and nearest neighbor) tested, we chose UPGMA, because it presented the highest CCC, the lowest stress, and the lowest distortion $(0.75,14.74$, and 2.17 , respectively) (Table 3). The CCC of 0.75 reveals good adjustment between the distances obtained in the dissimilarity matrix of the Jaccard complement and the cophenetic matrix, with consequent consistency in the cluster analysis. The CCC found here was satisfactory, given that values greater than 0.56 reflect a good agreement between the dissimilarity matrices (Vaz Patto et al., 2004). According to Cruz and Carneiro (2003), higher CCC values mean lower distortion caused when grouping individuals, which is normally obtained by UPGMA.

Table 3. Cophenetic correlation coefficient (CCC), stress, and distortion of the hierarchical methods: UPGMA (unweighted pair-group method using arithmetic averages), single linkage LS-nearest neighbor, and Ward.

\begin{tabular}{l|c|c|c}
\hline & UPGMA & LS & Ward \\
\hline CCC & $0.75^{* *}$ & $0.72^{* *}$ & $0.50^{* *}$ \\
\hline Stress (\%) & 14.74 & 27.60 & 41.81 \\
\hline Distortion (\%) & 2.17 & & \\
\hline
\end{tabular}

**Significant at a $1 \%$ level, by the $t$-test.

The dendrogram of genetic dissimilarities based on ISSR, obtained by the UPGMA method, is shown in Figure 2. The analysis allowed for the division of the individuals into four groups, based on a cutoff point of 0.33, according to the criterion proposed by Mojena (1977). Group I is composed of 21 genotypes $(14,19,10,15,23,11,18,20,17,4,1,21,6,7,8,16,5,12,2$, 9 , and 24); groups II, III, and IV are formed by only one genotype each (3, 13, and 22, respectively).

Genetics and Molecular Research 16 (3): gmr16039706 


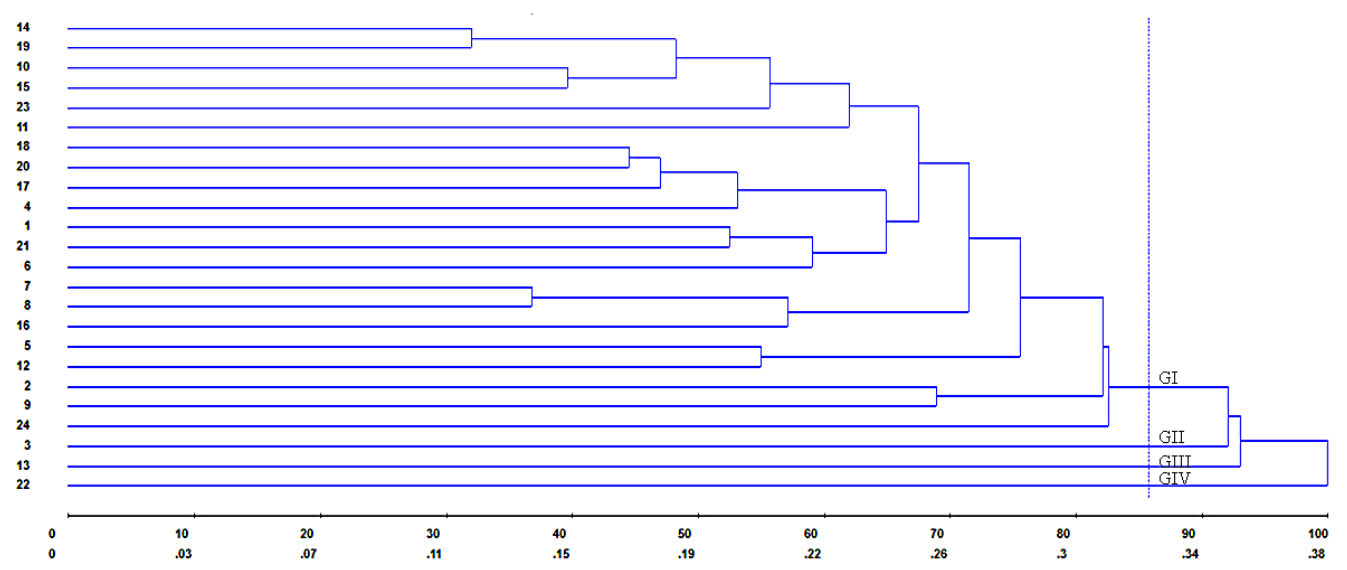

Figure 2. Dendrogram of the genetic dissimilarity among 24 Hymenaea courbaril trees, using unweighted pair group method with arithmetic mean (UPGMA) method based on the arithmetic complement of Jaccard's index.

Four groups were formed by the Tocher optimization method (Table 4). Of the 24 genotypes, 20 were allocated to the first group. Individuals 9 and 13 were allocated to the second group. The third and fourth groups were composed of genotypes 3 and 22, respectively.

Results from the Tocher clustering method were consistent with those obtained with UPGMA with similarities in the composition of groups despite the different criteria each method adopts to classify the genotypes. Most (95.24\%) of the individuals clustered in the group I by the UPGMA method were also allocated in the group I by the Tocher method. Both methods agreed in allocating individuals 3 and 22 in separate groups. The high agreement between the two methods (UPGMA and Tocher) in the distinction of the genotype groupings provides bases for more certain inferences about genetic diversity among the evaluated individuals. The use of more than one clustering method, given the differences in hierarchization, optimization, and ordering of groups, allows for their classifications to be complementary, as a function of the criteria each method uses, preventing erroneous inferences from being adopted in the allocation of materials within a certain group of genotypes (Arriel et al., 2006). Ramalho et al. (2016) studied genetic diversity in Bertholletia excelsa Bonpl. genotypes with the use of ISSR markers and also observed that cluster analysis by the UPGMA and Tocher methods agreed partially.

\begin{tabular}{|c|c|}
\hline Cluster & Genotypes \\
\hline $\mathrm{I}$ & $14,19,15,10,23,21,17,18,20,8,7,4,1,6,12,5,11,16,2$, and 24 \\
\hline II & 9 and 13 \\
\hline III & 3 \\
\hline IV & 22 \\
\hline
\end{tabular}

In programs aimed at seedling production for the restoration of degraded areas, information about the genetic diversity of trees that provide seeds is useful. The existence of large genetic distances among $H$. courbaril individuals indicates a strong genetic diversity that can be used for the selection of more divergent genotypes for seed collections in projects

Genetics and Molecular Research 16 (3): gmr16039706 
for the reforestation of degraded areas. The results found in this study can also be used in environmental actions aimed at the conservation and sustainable use of the species since the genetic diversity in natural populations of $H$. courbaril has been affected by the logging activity (Carneiro et al., 2011; Lacerda et al., 2008). Therefore, we recommend the in situ conservation of the evaluated genotypes aiming to maintain the genetic variability of the species in the north of Mato Grosso State.

In conclusion, the ISSR markers were efficient to characterize the genetic diversity among the $H$. courbaril genotypes, detecting polymorphism. Both the UPGMA and Tocher methods revealed the formation of four distinct groups, demonstrating that there is genetic dissimilarity among the analyzed genotypes. A collection of seeds for seedling production in programs for the recovery of degraded areas can include all the evaluated individuals, and wherein the most genetically divergent ( 3 and 22 ) should be prioritized.

\section{Conflicts of interest}

The authors declare no conflict of interest.

\section{ACKNOWLEDGMENTS}

The authors wish to thank FAPEMAT (Projeto: Conservação e uso de espécies vegetais nativas da região Amazônica com potencial econômico para a região Norte do Estado de Mato Grosso; process \#166159/2014). V.D. Rocha received an undergraduate scholarship from PROBIC/UNEMAT.

\section{REFERENCES}

Araújo FS, Pacheco MV, Vieira FA, Ferrari CS, et al. (2016). ISSR molecular markers for the study of the genetic diversity of Mimosa caesalpiniaefolia Benth. Idesia 34: 47-52. https://doi.org/10.4067/S0718-34292016000300007

Arriel NHC, Di Mauro AO, Di Mauro SMZ, Bakke AO, et al. (2006). Técnicas multivariadas na determinação da diversidade genética em gergelim usando marcadores RAPD. Pesqui. Agropecu. Bras. 41: 801-809. https://doi. org/10.1590/S0100-204X2006000500012

Botstein D, White RL, Skolnick M and Davis RW (1980). Construction of a genetic linkage map in man using restriction fragment length polymorphisms. Am. J. Hum. Genet. 32: 314-331.

Carneiro FS, Lacerda AEB, Lemes MR, Gribel R, et al. (2011). Effects of selective logging on the mating system and pollen dispersal of Hymenaea courbaril L. (Leguminosae) in the Eastern Brazilian Amazon as revealed by microsatellite analysis. For. Ecol. Manage. 262: 1758-1765. https://doi.org/10.1016/j.foreco.2011.07.023

Costa DFD, Vieira FDA, Fajardo CG and Chagas KPTD (2015). Diversidade genética e seleção de iniciadores ISSR em uma população natural de mangaba (Hancornia speciosa Gomes) (Apocynaceae). Rev. Bras. Frutic. 37: 970-976. https://doi.org/10.1590/0100-2945-246/14

Cruz CD (2006). Programa Genes: Biometria. 1st edn. Universidade Federal de Viçosa, Viçosa.

Cruz CD and Carneiro PCS (2003). Modelos biométricos aplicados ao melhoramento de plantas. 2nd edn. Universidade Federal de Viçosa, Viçosa.

Doyle JJ and Doyle JL (1987). A rapid DNA isolation procedure for small amounts of fresh leaf tissue. Phytochem. Bull. 19: 11-15.

Duarte JF, de Carvalho D and Vieira FA (2015). Genetic conservation of Ficus bonijesulapensis RM Castro in a dry forest on limestone outcrops. Biochem. Syst. Ecol. 59: 54-62. https://doi.org/10.1016/j.bse.2015.01.008

Faleiro FG (2007). Marcadores genético-moleculares aplicados a programas de conservação e uso de recursos genéticos. 1st edn. Embrapa Cerrados, Planaltina.

Gois IB, Ferreira RA, Silva-Mann R, Blank MDFA, et al. (2014). Diversidade genética entre indivíduos de Spondias lutea L. procedentes do baixo São Francisco sergipano, por meio de marcadores RAPD. Rev. Arvore 38: 261-269. https:// doi.org/10.1590/S0100-67622014000200006

Genetics and Molecular Research 16 (3): gmr16039706 
Genetic diversity in Hymenaea courbaril L.

Kageyama PY, Sebbenn AM, Ribas LA, Gandara FB, et al. (2003). Diversidade genética em espécies arbóreas tropicais de diferentes estágios sucessionais por marcadores genéticos. Sci. For. 64: 93-107.

Lacerda AEB, Kanashiro M and Sebbenn AM (2008). Effects of reduced impact logging on genetic diversity and spatial genetic structure of a Hymenaea courbaril population in the Brazilian Amazon Forest. For. Ecol. Manage. 255: 10341043. https://doi.org/10.1016/j.foreco.2007.10.009

Lorenzi H and Matos FJA (2002). Plantas medicinais no Brasil: nativas e exóticas. 1st edn. Instituto Plantarum de Estudos da Flora, Nova Odessa.

Lorenzoni RM, Soares TCB, Santiago VF, Silva JA, et al. (2014). Utilização de marcadores ISSR na avaliação da divergência genética entre acessos de biribazeiro. Rev. Bras. Frutic. 36: 251-257. https://doi.org/10.1590/S010029452014000500029

Marinho MGV, Silva CC and Andrade LHC (2011). Levantamento etnobotânico de plantas medicinais em área de caatinga no município de São José de Espinharas, Paraíba, Brasil. Rev. Bras. Pl. Med 13: 170-182. https://doi.org/10.1590/ $\underline{\text { S1516-05722011000200008 }}$

Melo MGG and Mendes AMS (2005). Jatobá Hymenaea courbaril Informativo Técnico Rede de Sementes da Amazônia. 9th edn. Universidade do Estado do Amazonas, Manaus.

Mojena R (1977). Hierarchical grouping methods and stopping rules: an evaluation. Comput. J. 20: 359-363. https://doi. org/10.1093/comjnl/20.4.359

Oliveira WL, Medeiros MB, Moser P, Pinheiro R, et al. (2011). Regeneração e estrutura populacional de jatobá-da-mata (Hymenaea courbaril L.), em dois fragmentos com diferentes graus de perturbação antrópica. Acta Bot. Bras. 25: 876-884. https://doi.org/10.1590/S0102-33062011000400014

Pacheco FV, Pereira CR, Silva RLD and Alvarenga ICA (2013). Crescimento inicial de Dalbergia nigra (Vell.) Allemão ex. Benth. (Fabaceae) e Chorisia speciosa A.St.-Hil (Malvaceae) sob diferentes níveis de sombreamento. Rev. Arvore 37: 945-953. https://doi.org/10.1590/S0100-67622013000500017

Ramalho AB, Rossi AAB, Dardengo JFE, Zortéa KEM, et al. (2016). Diversidade genética entre genótipos de Bertholletia excelsa por meio de marcadores moleculares ISSR. Floresta 46: 207-214. https://doi.org/10.5380/rf.v46i2.41970

Reddy MP, Sarla N and Siddiq EA (2002). Inter simple sequence repeat (ISSR) polymorphism and its application in plant breeding. Euphytica 128: 9-17. https://doi.org/10.1023/A:1020691618797

Rezende RKS, Paiva LV, Paiva R, Chalfun A, Junior., et al. (2009). Divergência genética entre cultivares de gérbera utilizando marcadores RAPD. Cienc. Rural 39: 61-72. https://doi.org/10.1590/S0103-84782009005000176

Rivas LH, Giustina LD, Luz LN, Karsburg IV, et al. (2013). Genetic diversity in natural populations of Theobroma subincanum Mart. in the Brazilian Amazon. Genet. Mol. Res. 12: 4998-5006. https://doi.org/10.4238/2013. October. 24.12

Rodrigues SM, Moura EF, Ramos GK and Oliveira MS (2016). Genetic variability analysis of Byrsonima crassifolia germplasm collected in Pará State using ISSR markers. Genet. Mol. Res. 15: 1-11. https://doi.org/10.4238/ gmr15048887

Santana IBB, Oliveira EJ, Soares Filho WS, Ritzinger R, et al. (2011). Variabilidade genética entre acessos de umbucajazeira mediante análise de marcadores ISSR. Rev. Bras. Frutic. 33: 868-876. https://doi.org/10.1590/S0100$\underline{29452011005000090}$

Sebbenn AM (2002). Número de árvores matrizes e conceitos genéticos na coleta de sementes para reflorestamentos com espécies nativas. Rev. Inst. Flor 14: 115-132.

Silva BM, Rossi AAB, Dardengo JDFE, Araujo VAAC, et al. (2016). Diversidade genética estimada com marcadores entre sequências simples repetidas em cultivos comerciais de Cupuaçuzeiro. Cienc. Rural 46: 108-113. https://doi. org $/ 10.1590 / 0103-8478 \mathrm{cr} 20141634$

Silva BM, Rossi AAB, Tiago AV, Schmitt KFM, et al. (2017). Genetic diversity of Cajazeira (Spondias mombin L.) in three geographic regions. Genet. Mol. Res. 16: 1-11. https://doi.org/10.4238/gmr16018946

Vaz Patto MC, Satovic Z, Pego S and Fevereiro P (2004). Assessing the genetic diversity of Portuguese maize germplasm using microsatellite markers. Euphytica 137: 63-72. https://doi.org/10.1023/B:EUPH.0000040503.48448.97

Genetics and Molecular Research 16 (3): gmr16039706 